
gridoriyhe952@gmail.com, ORCID: 0000-0003-1580-6739, $\mathrm{PhD}$, Associate professor Iryna Merylova iryna.merylova@gmail.com, ORCID: 0000-0003-2019-0780,

Web of Science ResearcherID: Y-9263-2019, Senior lecturer Sergiy Podolynnyi, podolynnyi.serhii@pgasa.dp.ua, ORCID: 0000-0003-3480-8035, Anna Sivakova, annsivakovs@gmail.com, ORCID: 0000-0002-2559-3530, Prydniprovs'ka State Academy of Civil Engineering and Architecture, Dnipro DOI: $10.32347 / 2076-815 x .2020 .72 .202-213$

\title{
REDEVELOPMENT OF THE INDUSTRIAL TERRITORIES. DVORETS TRUDA IN DNIPRO: HISTORY, STAGES OF CONSTRUCTION, MODERN CONDITION
}

The article considers the "Dvorets Truda" in Dnipro in the context of its historical transformations. The main goal of the article is to reveal the historical and cultural significance of this architectural object as a unique monument of Soviet constructivism of the interwar period to indicate the value of its heritage.

The article is also aimed at analyzing the current state of the "Dvorets Truda", identifying the negative characteristics of the object and assessing its potential as an external educational institution of urban significance in the process of redevelopment of industrial territories of Dnipro. "Dvorets Truda" had a title of protection in the times of Soviet Union, but in 1990-ies the documents, which proved the national status of the landmark, were lost. Currently there is no information on modern reconstruction and design proposals. However, renovation works started and the initial authentic look of the building (colour and window sash system) is being changed.

It is worth mentioning that, on the one hand, the object is closely connected with its peculiarities which is a disadvantage. But on the other hand, it can be turned into advantage if to revitalize its functional territory and to use unique characteristics of the object as a "growth point". Understanding social and economic factors can provide insight into tendencies and terms of possible changes in territories environment. Social and architectural parts of pre-project investigations can show definite directions of the desired changes in town planning structure. Complex of social and economic, social and architectural recommendations allows for appropriate design and architectural, functional and reconstruction activities. 
Keywords: architectural monument, Soviet constructivism, Dvorets Truda, outof-school educational institution, redevelopment of industrial territories.

Introduction. "Dvorets Truda" ("Labor Palace", further as "DT"), had a title of protection in the times of Soviet Union, which was specified in "Historical and cultural monuments of Ukrainian SSR" - a reference catalogue of 1987 [1]. In 1990ies the documents, which proved the national status of the landmark, were lost.

Nowadays the story of awarding the status is quite ambiguous. Later, as a result of public efforts, some documents to award the status of "Local monument of architecture" have been prepared. A famous historian, candidate of historical sciences M. Kavun, stated in this interview, "I prepared a quite comprehensive historical information on the building in 2014 (it was a part of documents about award status). Last year the registration card of DT building and historical information were sent to the Ministry of Culture in Kiev. The building of DT "claimed" to be called a "local monument of architecture" [2]. Finally, this issue was considered by a special committee of the Ministry of Culture and the building got the status of local monument of architecture with the registry entry in the national register of monuments [3].

However, it appeared to be no registry entry in the register of the Ministry of Culture. City administration officials in Dnipro claim that this matter is not brought to a close. According to the law, the designation document should be signed by the property owner (BTS - VESTA LLC.). But currently there is no signature. The process of creating, developing, maintaining and even changing the name of this building has a very complicated path [3].

"Dvorets Truda" was its design name in mid 1920-ies. The building was opened as the "Culture Palace of Metalists". After that the word "metalist" was replaced by "metallurgist". Later it became the "Culture Palace of Metallurgists" (in 1930 -ies and post-war times). In 1955 the renovated building was officially called "The Bolshoi Theatre" similarly to the one in Moscow. Sometimes only the premises of the theatre in the palace were called this way. From 1960-ies till the dissolution of the USSR it was officially called the "Culture Palace of Metallurgists named after Ilyich". In 1992 to mark the first Independence anniversary of Ukraine, the palace was renamed as "Ukrainian house" (by association with former museum of Lenin in Kiev) and it was announced in all local newspapers. However, the new name didn't take flight [2]. S. Revskiy in his article published in 2004 called it "Dvorets Truda" as the most appropriate title, which clearly reflected its purpose [4]. This name is used in the article. It is supposed that these circumstances are based on exact and important reasons for modern efforts to revitalize it.

Analysis of recent research and publications. There are only general facts presented about the building in a number of articles and publications by S. Revskiy 
$[4,5]$, on the website of the international organization "Institute of Ukrainian Studies". Stylistic peculiarities and instances of its design and construction are considered in scientific papers of V. Starostin and O. Ignatov [6,7]. There are other published sources which provide some fragments of information on the building. The main stages of establishment, functioning and current problems of DT were given in details and illustrations in poster presentation by Y. Koshmar and Y. Pakhniy. Comprehensible photo content is presented by A. Volok, A. Kostyuk and other authors.

The purpose of the article is to clarify social and architectural factors of development and maintenance of DT building, as well as to suggest further and efficient ways for pre-project study.

The methods of physical examination, analytical, historical and comparative analysis, archive materials and the Internet resources were used for the investigation of the topic.

The analysis of scientific works allowed identifying a number of issues studied.

Problem statement. Currently there is no information on modern reconstruction and design proposals. However, renovation works started and the initial authentic look of the building (colour and window sash system) is being changed. Thus, it is necessary for the owner to cooperate with the architects. Moreover, reasonable and appropriate approach to the building revitalization is urgent. It is also important to take into account the peculiarities of its development and maintenance and define the best possible principles to reopen the building.

History, current status and development opportunities. This part of the city was built relatively late. According to the master plan of 1817 , in the framework of standard residential development on the city's outskirts northeast, a site for parish church was planned. But only in 1885, when much territory was sold to the Society of Bryanskiy plant, the outskirts started to develop. As a result, the square called "Bryanskaya" appeared. But it was not the church to be built the first, as it was planned, but a locomotive shed in 1904 [7].

In 1909 the square was renamed as garden square "Sokolniki" - a place for leisure time for workers from the surrounding residential areas. The church (Nikolskaya) was built only in 1915 [7]. The chronology of the first stages of land development is quite significant and typical of its further history. The place was full of pragmatic and utilitarian spirit. It was a place to earn a lot of money, concentrated among just a few people. Spontaneous and infrequent attempts to contribute some elements of enlightenment and culture into that 
environment associated with some intentions to tone down depressive local community.

Certain measures were taken to develop territories for everyday and cultural life in the days of so called "Chechelovskaya Republic" (1908-1910). However, system approaches to solve social injustice are connected with the Soviet times. The peculiarities of social and cultural processes in USSR caused this situation. The motto "piece to huts, war to palaces" was implemented literally from the first days of the state. But very soon the authorities realized that it was impossible for public to do high-performance job and develop culturally among only huts. A programme of extensive cultural and educational, as well as architectural development was established. Its main social idea was "culture to public", first of all to proletariat. It led to the necessity to build cultural establishments close to enterprises and residential areas. Palaces were really necessary not only for restricted elite strata, but for the community. The second surge of interest in "palaces for people" topic arose in 1970-ies. However, it was not an exemplary period in architectural context.

A decisive step in this direction was made in 1925. "Yuzhstal enterprise" (a union of the biggest metallurgical enterprises in USSR) reached a decision to build DT - a significant object of that time. City administration proposed a location in the city center, but metallurgists insisted on establishing a cultural center in a proletarian district [1].

The plans were ambitious and the project plan specified: a theatre with 3150 seat auditorium, a 600-seat conference room, lecture rooms of 500-seats, spacious reading halls and a great number of other club premises. An all-union contest for the best project of DT was announced and such famous architects as A. Grinberg, A. Vlasov, G. Barkhin, M. Barkhin and others participated in it $[1,8]$.

Local authorities had to provide funding of the construction but refused an expensive project plan. It was impossible till the end to overcome that giantism spirit, which embraced people. The project of A. Krasnoselskyi, implemented on the request of local administration, was also monumental. It was realized step by step: $05.08 .1926-$ foundation laying; 07.11.1928 - a unit for club was finished; in 1934 - construction works of a theatre unit with 1600-seat auditorium began; in 1938 - decoration work finished. The square garden Sokolniki was reconstructed and given a status of a park near "Dvorets Truda" [1, 8, 9].

That time, according to historians, social environment was revived due to DT. However, key negative factors still remained: high pollution level from industrial waste, poor roads, low quality dwellings, underdeveloped public service network $[10]$.

During the city occupation by Nazi Germany, DT was undamaged as a building, but fully devastated inside. All things of value were taken out from 
premises, wooden equipment and pieces of interior were broken down for firewood, the park was cut down and turned into a pasture. It took almost the same time to renovate the palace after vandals as to build it: 1945 - renovation of sports hall and a few right flank premises; 24.07.1948 - opening of the theatre auditorium; 1950 - the first stage of renovation was finished; 18.12.1955 - opening of the theatre; 1956 - final stage of renovation. Wardamaged enterprises and the city center were the first to be reconstructed. In these conditions DT and its surrounding area remained neglected outskirts for about 10 years $[8,10,11]$.

After the reconstruction in 1960-1970-ies DT was in demand even more than a concert venue - The Opera and Ballet House built in 1974. Acoustic excellence of the auditorium attracted singers and musicians. The surrounding territory infrastructure was being improved. The network of public and cultural service was being grown. In May 1986 the restoration of Bryankaya (Nikolskaya) church was finished and turned into the Organ music house. In 1989 an underground station was being built and became an underground line which connected new residential districts such as "Krasniy Kamen"" and "Parus" with city center [12].

These structural changes improved the status of territories for a short period of time. But simultaneously the degradation was taking place in other direction - manufacturing activity at surrounding enterprises went downwards. Employment layoffs significantly deteriorated social standards of residents in this district. Residential areas around DT and low quality dwellings became full of new stratum of unemployed people. In 1989 redecoration works in DT were made for the last time. In conditions of total crisis, the demand for the building of this function area decreased. The object became inappropriate for its owner - plant named after Petrovskiy that drastically reduced its profitability. For the last three years it has changed its owners three times. Contradictions since the times of the development of this building have come to its peak - in 2000-ies local authorities came up with an idea to demolish the building $[2,13]$. 


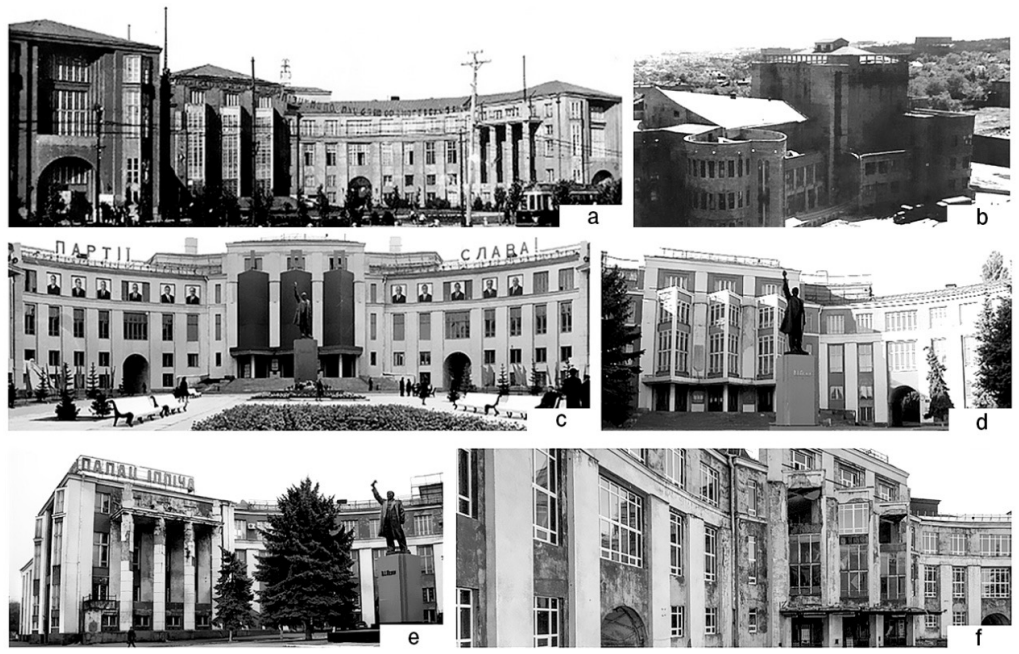

Fig. 1. Photos of "Dvorets Truda" at the most distinctive stages: a) 1930 ; b) 1935 ; c) 1970; d) 2001 ; e) 2004 ; f) 2018 .

Nowadays the owner of the building is BTS VESTA LLC. A new proprietor has taken first steps to break the deadlock. Urgent reconstruction has started (roofing and windows renewal) in order to arrange office and trade space. In the summer 2018 a final disco of the "Construction" fest, where 500 young people and foreign musicians took place, was organized in the left flank of DT, in the cinema unit [3]. The history line of the palace activity, which took 90 years, indicates that its performance definitely depends on the standard and quality of living in the surrounding community (Fig. 1).

"Dvorets Truda" as cultural facility has own advantages and disadvantages. Advantages:

high potential of functional and technological base;

good transport accessibility;

a square garden in proximity;

exclusive architecture;

no equivalent auditorium with such acoustic properties in the city; medial location in the system of dense residential developments; high probability to obtain a status of "monument of architecture"; possibility of parking facilities. 


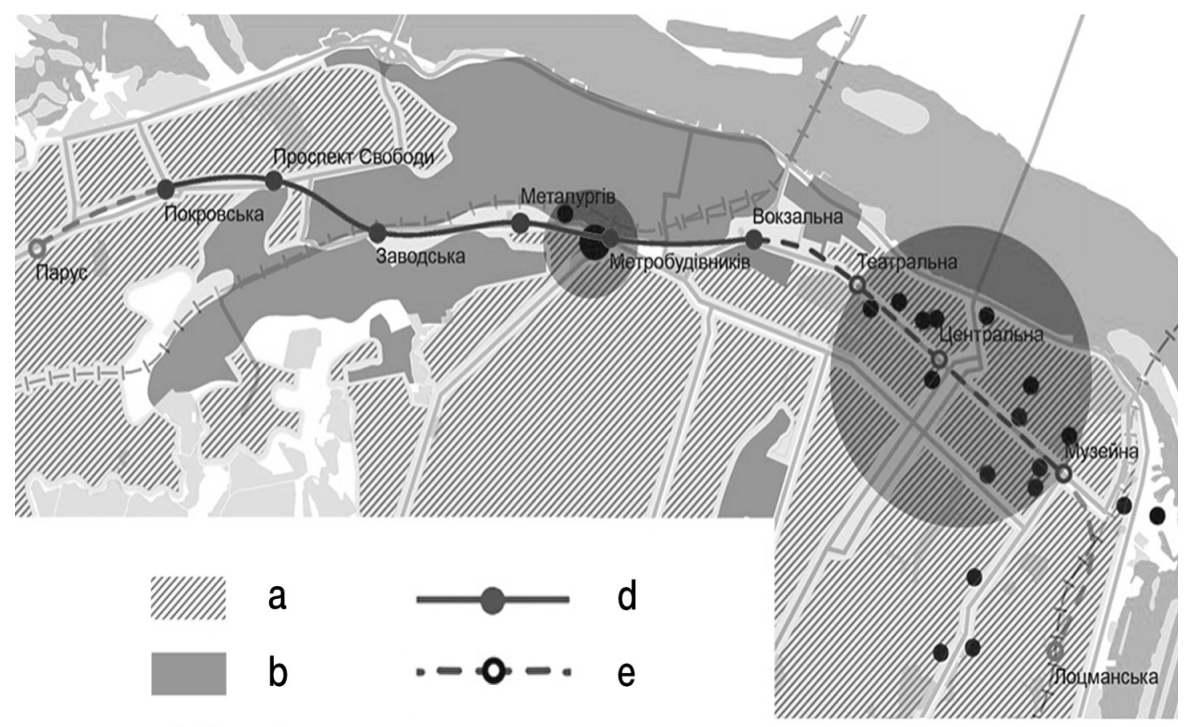

- C

Fig.2 Perspective underground links with city center location by 2022: a) - residential districts, b) - industrial areas, c) - educational and cultural facilities, d) - currently available underground stations, e) - underground stations to be built. 
Disadvantages:

ecological aspect - proximity to industrial objects with high pollution level from industrial waste;

remoteness from key urban landscape - the Dnieper river;

incompetence of proprietors and local authorities;

high rate of destruction;

uncontemporary authentic functional programme;

no parking facilities;

the image spoilt by decommunization;

high investments;

depressive district (housing prices, crime rate).

It is worth mentioning that, on the one hand, the object is closely connected with its peculiarities - which is a disadvantage. But on the other hand, it can be turned into advantage if to revitalize its functional territory (Fig. 2) and to use unique characteristics of the object as a "growth point" $[13,14]$.

\section{Conclusions:}

Cultural and educational establishments of 1920-1930-ies - palaces - are a phenomenon in the history of architecture. Preservation of these objects is an important aspect incorporating our country into global trends.

The problems associated with reconstruction of such facilities, and DT in Dnipro in particular, should be solved only in terms of professional designs based on prior pre-project studies under 4 directions: social, economic, town planning and architectural. It is useful to consider them in blocks with dominating social component.

Understanding social and economic factors can provide insight into tendencies and terms of possible changes in territories environment. Social and architectural parts of pre-project investigations can show definite directions of the desired changes in town planning structure. Complex of social and economic, social and architectural recommendations allows for appropriate design and architectural, functional and reconstruction activities.

\section{Література}

1. Памятники градостроительства и архитектуры Украинской ССР. Иллюстрированный путеводитель, № 2, Киев, Будивельник, 1985.

2. Кавун М. Дворец Ильича - умирающий шедевр конструктивизма. URL: https://gorod.dp.ua/news/65074 (дата звернення: 2019-8-10).

3. ДК Ильича станет памятником архитектуры национального значения. URL: https://www.gorod.dp.ua/news/139224 (дата звернення: 2019-8-10).

4. Ревский С.Б., Академические тенденции в советской архитектуре конструктивизма и функционализма (на примере Дворца труда в Днепропетровске), Строительство, материаловедение, машиностроение: сборник научных трудов. Днепропетровск, ПГАСА, 2004. Выпуск. 27, часть 3. 
5. Ревский С.Б., Формирование и развитие исторического центра г. Днепропетровска. Памятники русской архитектуры и монументального искусства. Стиль, атрибуции, датировки. Москва, Наука, 1983.

6. Старостин В.С., Губернаторские дворцы, столица степной области. Днепропетровск: очерки истории города, Днепропетровск, Днипрокнига, 2004, ISBN 966-7691-68-3.

7. Асеев Ю., Грицай М., Игнатов О. и др. Очерки по истории архитектуры Украинской ССР: дооктябрьский период, Киев, 1957.

8. Екатеринославский дворец труда (Дворец Ильича). URL: https://www.shukach.com/ru/node/14785 (дата звернення: 2019-8-10).

9. Бархин М., Мастера советской архитектуры об архитектуре. Москва: Искусство, 1975.

10. Балдин В., Белоусов В., Бочаров Ю., Архитектура СССР 1917-1987 гг. Москва: Стройиздат, 1987.

11. Головко Г., Архитектура Советской Украины, Москва: Стройиздат, 1973.

12. A. Buttlar, C. Heuter, Architektur der 60-er Jahre Wiederentdeckung einer Epoche. Berlin: Jovis. 2007.

13. Мерилова І.О. Історичні етапи розвитку будівель позашкільної освіти на Дніпропетровщині. Сучасні проблеми архітектури та містобудування: наук.-техн. зб. Київ, 2015, Вип. 38.

14. Ковальський Л.М., Мерилова I.О. Мережа закладів позашкільної освіти в структурі міської забудови (на прикладі м. Дніпропетровська). Досвід та перспективи розвитку міст України. Проблеми реконструкції в теорії та практиці містобудування: зб. наук. пр. Київ, 2014, Вип. 27.

к.т.н., доцент Невгомонный Г.У., к.арх., доцент Мерилова И.А., Подолинный С.И., Сивакова А.С., ГВУЗ «Приднепровская государственная академия строительства и архитектуры», г. Днепр

\section{РЕДЕВЕЛОПМЕНТ ИНДУСТРИАЛЬНЫХ ТЕРРИТОРИЙ. ДВОРЕЦ ТРУДА В ДНЕПРЕ: ИСТОРИЯ, ЭТАПЫ СТРОИТЕЛЬСТВА, СОВРЕМЕННОЕ СОСТОЯНИЕ}

В статье рассматривается Дворец труда в Днепре в контексте его исторических преображений. Главной целью статьи было раскрыть историко-культурную значимость архитектурного объекта, как уникального памятника архитектуры советского конструктивизма междувоенного периода, обозначить ценность его наследия. Статья также направлена на анализ нынешнего состояния Дворца труда, выявление негативных характеристик объекта и оценку его потенциала, в качестве внешкольного учебного заведения городского значения в процессе редевелопмента индустриальных территорий города Днепр.

«Дворец труда» ранее носил охранный титул, однако документы, подтверждающие национальный статус памятника, были утрачены, 
начались ремонтные работы, и первоначальный аутентичный внешний вид здания (покрытие кровли, система окраски фасада и структура оконных створок) был изменен, не смотря на отсутствие информации о современных реконструкциях и проектных предложениях по восстановлению объекта.

Стоит отметить, что «Дворец труда», как городской культурный объект, имеет высокий потенциал для города, раскрываемый путем оживления его функциональной территории и использования уникальных характеристик объекта в качестве «точки роста». Понимание социальных и экономических факторов может дать представление о тенденциях и условиях возможных изменений в окружающей среде территорий. Социальная и архитектурная части предпроектных исследований могут показать определенные направления желаемых изменений в градостроительной структуре. Комплекс социальноэкономических, социальных и архитектурных рекомендаций позволяет проводить соответствующие проектно-архитектурные, функциональные и реконструкционные работы.

Ключевые слова: памятник архитектуры, советский конструктивизм, дворец труда, внешкольное учебное заведение, редевелопмент индустриальных территорий.

к.т.н., доцент Невгомонний Г.У., к.арх., доцент Мерилова I.О., Подолінний С.І., Сівакова А.С., ДВНЗ «Придніпровська державна академія будівництва та архітектури», м. Дніпро

\section{РЕДЕВЕЛОПМЕНТ ІНДУСТРІАЛЬНИХ ТЕРИТОРІЙ. ПАЛАЦ ПРАЦІ В ДНІПРІ: ІСТОРІЯ, ЕТАПИ БУДІВНИЦТВА, СУЧАСНИЙ СТАН}

У статті розглядається Палац праці в Дніпрі в контексті його історичних перетворень. Головною метою статті було розкрити історико-культурну значимість архітектурного об'єкта, як унікальної пам'ятки архітектури радянського конструктивізму міжвоєнного періоду, позначити цінність його спадщини. Стаття також спрямована на аналіз нинішнього стану Палацу праці, виявлення негативних характеристик об'єкта та оцінку його потенціалу, як позашкільного навчального закладу міського значення в процесі редевелопмента індустріальних територій міста Дніпро.

«Палац праці» раніше носив охоронний титул, проте документи, що підтверджують національний статус пам'ятки архітектури, були втрачені, почались ремонтні роботи, та первісний автентичний зовнішній вигляд будівлі 
(покриття покрівлі, система забарвлення фасаду і структура віконних стулок) було змінено, не дивлячись на відсутність інформації про сучасні реконструкції та проектні пропозиції з відновлення об'єкта.

Варто відзначити, що «Палац праці», як міський культурний об'єкт, має високий потенціал для міста, який розкривається шляхом оживлення його функціональної території та використовуванням унікальних характеристик об'єкта в якості «точки зростання». Розуміння соціальних та економічних чинників може дати уявлення про тенденції та умови можливих змін у навколишньому середовищі територій. Соціальна та архітектурна частини передпроектних досліджень можуть показати певні напрямки бажаних змін у містобудівній структурі. Комплекс соціальноекономічних, соціальних та архітектурних рекомендацій дозволяє проводити відповідні проектно-архітектурні, функціональні та реконструкційні роботи.

Ключові слова: пам'ятник архітектури, радянський конструктивізм, палац праці, позашкільний навчальний заклад, редевелопмент індустріальних територій.

\section{REFERENCES}

1. Monuments of urban planning and architecture of the Ukrainian SSR. Illustrated Guide, № 2, Kyiv, Budivelnik, 1985. [in Russian]

2. M. Kavun, Ilyich Palace - a dying masterpiece of constructivism, 2011, August [Online].URL: https://gorod.dp.ua/news/65074 (date of appeal: 2019-8-10). [in Russian]

3. DT Ilyich becomes an architectural monument of national importance, 2017, November [Online]. URL: https://www.gorod.dp.ua/news/139224 (date of appeal: 2019-8-10). [in Russian]

4. S. Revskiy, Academic tendencies in Soviet architecture of constructivism and functionalism (based on the example of the Labor Palace in Dnepropetrovsk), Construction, materials science, mechanical engineering: collection of scientific works. Dnepropetrovsk, PSASA, 2004. Issue. 27, Part 3. [in Russian]

5. S. Revskiy, Formation and development of the historical center of Dnepropetrovsk. Monuments of Russian architecture and monumental art. Style, attribution, dating. Moscow, Nauka, 1983. [in Russian]

6. V. Starostin, Governor's palaces, Capital of the steppe region. Dnepropetrovsk: essays on the history of the city, Dnepropetrovsk, Dniprokniga, 2004, ISBN 966-7691-68-3. [in Russian] 
7. Y. Aseev, M. Gritsay, O. Ignatov and others, Essays on the history of architecture of the Ukrainian SSR: pre-October period, Kyiv: State Building of the USSR, 1957. [in Russian]

8. Ekaterinoslavsky Labor Palace (Ilyich Palace), 2012, October [Online]. URL: https://www.shukach.com/ru/node/14785 (date of appeal: 2019-8-10). [in Russian]

9. M. Barkhin, Masters of Soviet architecture. About architecture, Moscow: Art, 1975. [in Russian]

10. V. Baldin, V. Belousov, Y. Bocharov, The architecture of the USSR 19171987. Moscow: Stroyizdat, 1987. [in Russian]

11. G. Golovko, Architecture of Soviet Ukraine, Moscow: Stroyizdat, 1973. [in Russian]

12. A. Buttlar, C. Heuter, Architektur der 60-er Jahre Wiederentdeckung einer Epoche. Berlin: Jovis. 2007. [in German]

13. I. Merilova, Historical stages of development of extracurricular buildings in Dnipropetrovsk, Modern problems of architecture and urban planning, Kyiv, 2015. [in Ukrainian]

14. L. Kovalsky, I. Merilova, Network of out-of-school educational establishments in the structure of urban development (on the example of Dnepropetrovsk). Experience and prospects of urban development in Ukraine, Problems of reconstruction in the theory and practice of urban planning, Kyiv, 2014. [in Ukrainian] 